\title{
Gas exchange and antioxidant activity in seedlings of Copaifera langsdorffii Desf. under different water conditions
}

\author{
DEREK B.C.J. ROSA, SILVANA P.Q. SCALON, THAIS CREMON, FELIPE CECCON and DAIANE M. DRESCH \\ Faculdade de Ciências Agrárias, Universidade Federal da Grande Dourados, Rodovia \\ Dourados Itahum, Km 12, Bairro Rural, 79804970 Dourados, MS, Brazil
}

Manuscript received on June 30, 2017; accepted for publication on August 15, 2017

\begin{abstract}
The aim of this study was to evaluate gas exchange, efficiency of the photosynthetic apparatus, and antioxidant activity in Copaifera langsdorffii Desf. The seedlings were cultivated under different conditions of water availability, in order to improve the utilization efficiency of available water resources. The seedlings were cultivated in four different water retention capacities (WRC- 25\%, 50\%,75\%, and 100\%), and evaluated at four different time (T- 30, 60, 90, and 120 days). During the experimental period, seedlings presented the highest values for carboxylation efficiency of Rubisco (A/Ci), intrinsic water use efficiency (IWUE $=\mathrm{A} / \mathrm{gs}$ ), chlorophyll index, and stomatal opening, when grown in the substrate with $75 \% \mathrm{WRC}$, but the stomatal index (SI) was less the $25 \%$ WRC. The efficiency of photosystem II was not significantly altered by the treatments. Comparison between the extreme treatments in terms of water availability, represented by $25 \%$ and $100 \%$ WRC, represent stress conditions for the species. Water availability causes a high activity of antioxidant enzymes (superoxide dismutase, peroxidase, and catalase) in the plant.
\end{abstract}

Key words: antioxidant enzymes, chlorophyll a fluorescence, photosynthesis, water stress.

\section{INTRODUCTION}

Plant species are continuously exposed to a variety of stress factors, which limit their productivity and/or maximum expression of their genetic potential. Among these factors, water availability, the shortage of which affects leaf water potential, nutritional status, and leaf gas exchanges, might alter several metabolic and physiological processes; this, in turn, compromises the growth of plant species (Gonçalves et al. 2009, Cunha et al. 2013,

Correspondence to: Silvana de Paula Quintão Scalon

E-mail: silvanascalon@ufgd.edu.br
Campelo et al. 2015), and affects their occurrence and distribution (Sakamoto and Murata 2002).

Among the processes that could be affected by water stress, stomatal closure and reduction in the mesophyll conductance are particularly important, as they lead to a reduction in photosynthetic rate, and synthesis of ATP and antioxidant enzymes, in addition to damage to tissue membranes and impairing the activity of enzymes responsible for carbon fixation and assimilation processes (Loreto et al. 2003, Flexas et al. 2012, Campelo et al. 2015, Shao et al. 2007, Pompelli et al. 2010).

Copaifera langsdorffii Desf., popularly known as the diesel tree or "copaiba", is a species native 
to the Cerrado and semi-deciduous forests, but has a wide geographic distribution in the Brazilian territory. Due to the medicinal properties of its oil, this species faces intense over exploitation. Thus, it is crucial to investigate its agronomic and acclimation features to facilitate its ex situ cultivation. Moreover, with the increase in climatic variations, there has been an increasing demand for data on species that could be potentially deployed in degraded environments, wherein the plant-water relations get significantly affected (Nascimento et al. 2014, Santana et al. 2016).

Soil water availability is considered the factor with the greatest impact on the productivity of agricultural or forest species, which might influence their spatial distribution as well. Sustainable management of water resources, and the communication of research results to different countries and regions, as well as to different species and forest management regimes, continues to be difficult (Portes et al. 2006, Caldato and Schumacher 2013). Therefore, knowledge of the responses of species and their responses under the influence of different water conditions is fundamental, starting right from the first few months of growth, when the seedlings are highly susceptible to environmental variations.

In order to improve the use of available water resources, the aim of this study was to evaluate gas exchange, efficiency of the photosynthetic apparatus, and antioxidant activity of Copaifera langsdorffii Desf. seedlings cultivated under different conditions of water availability.

\section{MATERIALS AND METHODS}

The study was carried out at the Plant Nursery of the Faculty of Agrarian Sciences of the Federal University of Grande Dourados (UFGD), in the municipality of Dourados - MS, from June to October 2015. We used 60-day-old seedlings of Copaifera langsdorffii Desf.
The duration of the experiment was 120 days. A complete randomized design was used, with four replicates per treatment. The treatments were arranged in a $4 \times 4$ factorial scheme, with four values of water-availability (water retention capacity -WRC- $25 \%, 50 \%, 75 \%$, and $100 \%$ ) and four different evaluation times (T- 30, 60, 90, and 120 days). An experimental unit consisted of a vessel with two seedlings each.

WRC was calculated based on the methodology proposed by Souza et al. (2000). The 100\% WRC treatment was determined based on the amount of water retained after the drainage of excess water, while $25 \%, 50 \%$, and $75 \%$ WRC were obtained using the rule of three from the mass. Irrigation was provided on alternate days, and had individualized control, using the gravimetric method, with enough water to reach the pre-established mass for each WRC.

The substrate used to fill the vessels (6-L volume) was a mixture, comprising equal volumes of Bioplant ${ }^{\circledR}$, vermiculite, and dystroferric Red Latosol. Upon filling of substrate, the experimental units were transferred to the designated growth area in the nursery, under $30 \%$ shading, and covered with transparent plastic to protect them from precipitation.

At 30, 60, 90, and 120 days, leaf water potential $\left(\Psi_{\mathrm{w}}\right)$ of the seedlings was evaluated, using individual leaves belonging to the second pair of leaves fully expanded from the apex to the base, and the assay was performed between 10:00 and 11:00 $\mathrm{h}$ in the morning, immediately after the collection of the leaves, using a Scholander pressure chamber (Portable Plant Water Status Console - model 3115) (Scholander et al. 1964). The chlorophyll index (SPAD), the potential quantum efficiency of photosystem II $\left(\mathrm{F}_{\mathrm{v}} / \mathrm{F}_{\mathrm{M}}\right)$, and the maximum efficiency of the photochemical processes in photosystem II, obtained from chlorophyll a fluorescence data, were measured using the portable fluorometer model OS-30p (Opti-Sciences Chlorophyll Fluorometer, 
Hudson, USA). Photosynthetic and transpiration rates, stomatal conductance (gs), internal carbon dioxide concentration $(\mathrm{Ci})$, water use efficiency (WUE), carboxylation efficiency of Rubisco (A/ $\mathrm{Ci}$ ), and intrinsic water use efficiency (IWUE) were determined using the infrared gas analyzer (IRGA), ADC, model LCi PRO. The evaluation was performed using four seedlings per treatment, in the morning, between 08:00 and 11:00 h, in fully expanded leaves that were previously marked, and all measurements were performed on the same leaves, and only the data measured under a photosynthetic photon flux (PPF) higher than 700 mmol m $\mathrm{m}^{-2} \mathrm{~s}^{-1}$ was considered.

Stomatal opening was determined with the aid of digital camera Moticam 2000 coupled to the optical microscope by means of the program Motic Image 2000 and adjusted scales in the optical conditions. The stomatal index (SI \%) were calculated using the formula proposed by Salisbury (1928): $\mathrm{SI}=[\mathrm{NS} /(\mathrm{EC}+\mathrm{NS})] \times 100$, where NS is the number of stomata and EC the number of epidermal cells. The activity of the antioxidant enzymes, i.e., superoxide dismutase, peroxidase, and catalase, was measured in leaf and root tissues, following the methodology compiled by Broetto (2014).

Data for temperature and relative humidity during the experimental period (Figure 1) were obtained from the Embrapa Agropecuária Oeste Meteorological Station, in Dourados - MS.

The results were analyzed using the statistical program SISVAR 5.3 (Ferreira 2010). The data were subjected to analysis of variance, at the $5 \%$ significance level by the F test, and modeled using regression equations.

\section{RESULTS}

There was a significant interaction $(p<0.05)$ between the WRC and the evaluation time for photosynthetic rate $(\mathrm{A})$, transpiration $(\mathrm{E})$, stomatal conductance (gs), internal carbon dioxide concentration (Ci), WUE, IWUE, A/Ci, chlorophyll, stomatal opening and stomatal index, and enzymatic activity of peroxidase in the leaves, and for catalase in the

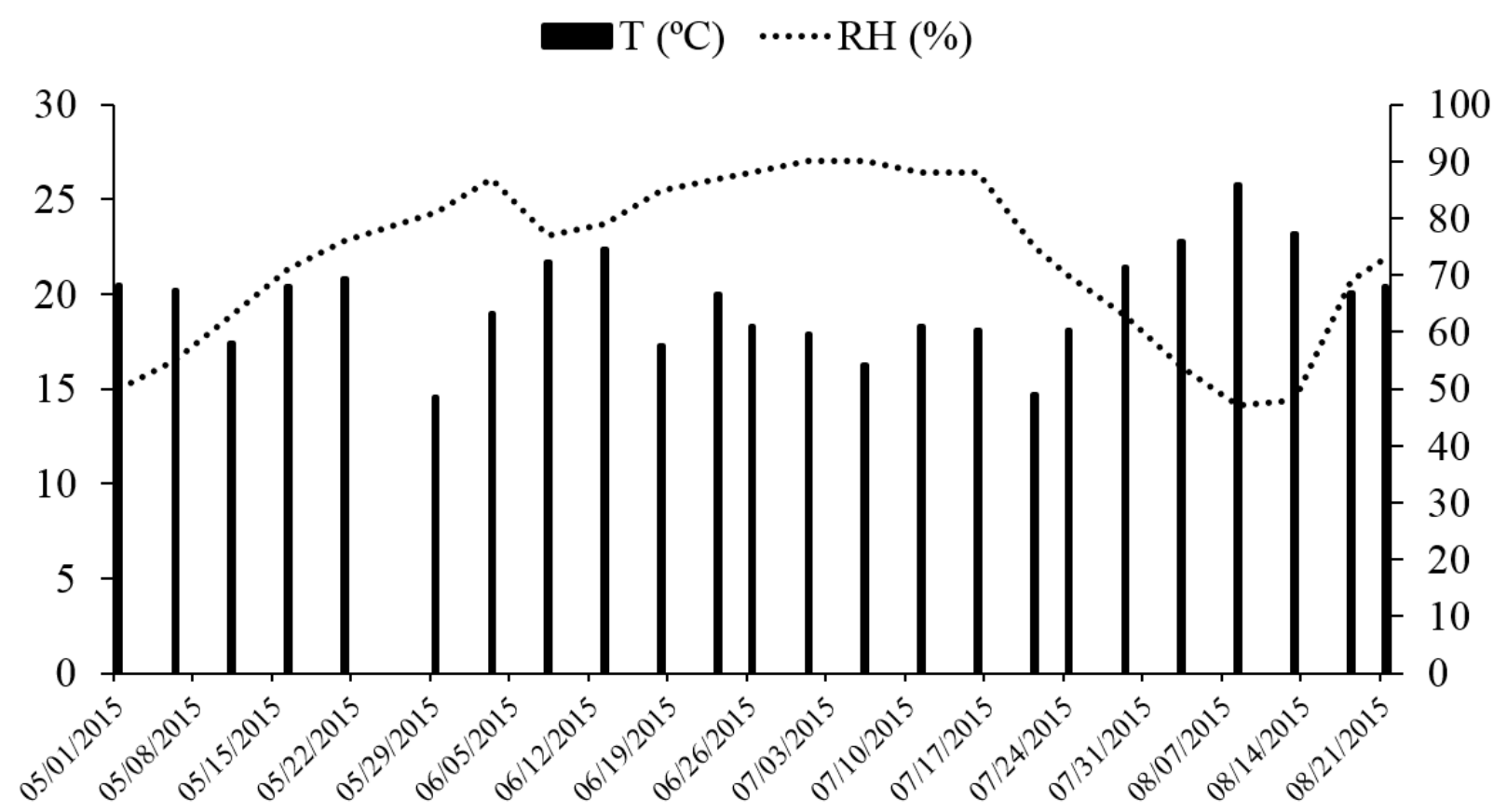

Figure 1 - Temperature and relative humidity during the experimental conduction period. 
roots. A significant isolated effect of the WRC $(p<0.01)$ was observed for the enzymatic activity of superoxide dismutase in both leaves and roots, and for peroxidase in the roots. The isolated effect of time was significant $(\mathrm{p}<0.01)$ only for the leaf water potential $\left(\Psi_{\mathrm{W}}\right)$. Neither $\mathrm{F}_{\mathrm{V}} / \mathrm{F}_{\mathrm{M}}$ nor the maximum efficiency of the photochemical process in photosystem II $\left(\mathrm{F}_{\mathrm{v}} / \mathrm{F}_{\mathrm{O}}\right)$ were influenced $(\mathrm{p}>0.05)$ by the studied factors, presenting mean values of 0.70 and 3.90 , respectively.

The maximum leaf water potential (Figure 2a) was observed at 86 days $(-1.23 \mathrm{MPa})$, however, there were no significant differences among the different WRC treatments, which mean value of $-1.4 \mathrm{MPa}$.

Photosynthetic rate (Figure 2b) was low for the seedlings cultivated under $100 \%, 25 \%$, and $50 \%$ WRC. Although for seedlings cultivated under $75 \% \mathrm{WRC}$, the minimum observed value was 3.28 $\mu \mathrm{m} \mathrm{mol} \mathrm{m} \mathrm{m}^{-2}$ (at 96 days), but on average, it is observed tendency of seedlings cultivated under this $75 \%$ WRC showed high photosynthetic rate.

Transpiration (Figure 2c), regardless of the evaluation time, had the lowest value under $25 \%$ WRC and the highest value under $100 \% \mathrm{WRC}$; for the other treatments, intermediate values were observed.

WUE under 25\% WRC presented a maximum value of $5.26 \mu \mathrm{mol} \mathrm{CO}_{2} \mathrm{mmol}^{-1} \mathrm{H}_{2} \mathrm{O}$, at 69 days (Figure 2d). For the other treatments, the WUE was inferior, and it differed between seedlings cultivated under $100 \%$ and $75 \%$ WRC, with lower values under $100 \%$ WRC. Data for seedlings cultivated under 50\% WRC did not fit well to the regression equations.

The minimum value of $\mathrm{Ci}$ was observed under $75 \% \mathrm{WRC}$, at 60 days $\left(218.26 \mu \mathrm{molmol}^{-1}\right)$, and from this point on, the values increased. For seedlings under $100 \%$ WRC, the performance decreased over time, with values of 296.95 and $252.55 \mathrm{molmol}^{-1}$, at 30 and 120 days, respectively (Figure 3a). For the remaining WRC treatments, the data did not present any pattern, as it did not show a good fit to the tested equations; however, at the end of the evaluation, the data were found to between the values obtained for $75 \%$ and $100 \%$ WRC.

$\mathrm{A} / \mathrm{Ci}$ values decreased over time in all the evaluated water resource conditions, while remaining high in the seedlings cultivated under $75 \%$, and low in the ones under $25 \%$ WRC. There was a greater temporal variation in the $\mathrm{A} / \mathrm{Ci}$ under $100 \%$ WRC (difference of $0.014 \mu \mathrm{molm}^{-1} \mathrm{~s}^{-1} \mu \mathrm{mol}$ $\mathrm{mol}^{-1}$ ) in comparison with the other treatments evaluated (Figure 3b).

The values for stomatal conductance of the seedlings cultivated under $25 \%$ WRC decreased throughout the evaluation period. For the $50 \%$ WRC treatment, the minimum value was $0.046 \mathrm{~mol}$ $\mathrm{m}^{-2} \mathrm{~s}^{-1}$, at 88 days. For the $75 \%$ and $100 \%$ WRC treatments, the minimum values $(0.037$ and 0.041 mol m $\mathrm{m}^{-2} \mathrm{~s}^{-1}$, respectively) were observed at 100 days (Figure 3c). The IWUE presented increasing values under 75\% WRC during the evaluation period, with the highest value $\left(110.99 \mu \mathrm{molCO}_{2} \mathrm{mmol}^{-}\right.$ $\left.{ }^{1} \mathrm{H}_{2} \mathrm{O}\right)$ at 120 days. For the $100 \%$ WRC treatment, the maximum value $\left(63.51 \mathrm{CO}_{2} \mathrm{mmol}^{-1} \mathrm{H}_{2} \mathrm{O}\right)$ was observed at 78 days (Figure $3 \mathrm{~d}$ ).

In general, the SPAD index was the highest throughout the evaluation period for seedlings cultivated under 75\% WRC. Maximum chlorophyll index of $45.62,51.33$, and 7.12 was observed at 67,77 , and 57 days, under the $25 \%, 75 \%$, and $100 \%$ WRC treatment, respectively. For seedlings cultivated under $50 \% \mathrm{WRC}$, the minimum value was 43.62 , at 88 days. At the end of the evaluation period, the chlorophyll index exceeded the values for the seedlings cultivated under 100 and $25 \%$ WRC treatments, reaching values close to those of seedlings cultivated under 75\% WRC (Figure 3e) capacity (WRC) and time.

Stomatal opening (Figure 4a) under 75\% WRC, was, in general, higher than in the other treatments, with the minimum value $(0.54 \mu \mathrm{m})$ observed at 54 days. The stomatal index (Figure 
a)

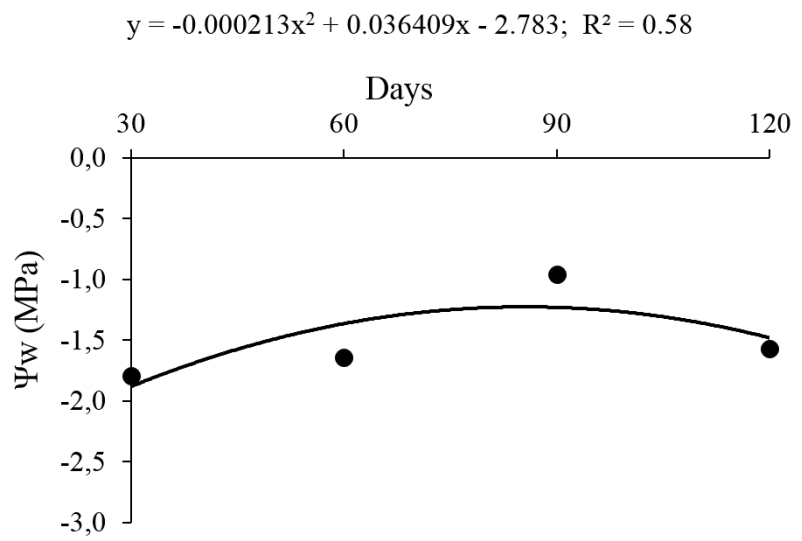

c)

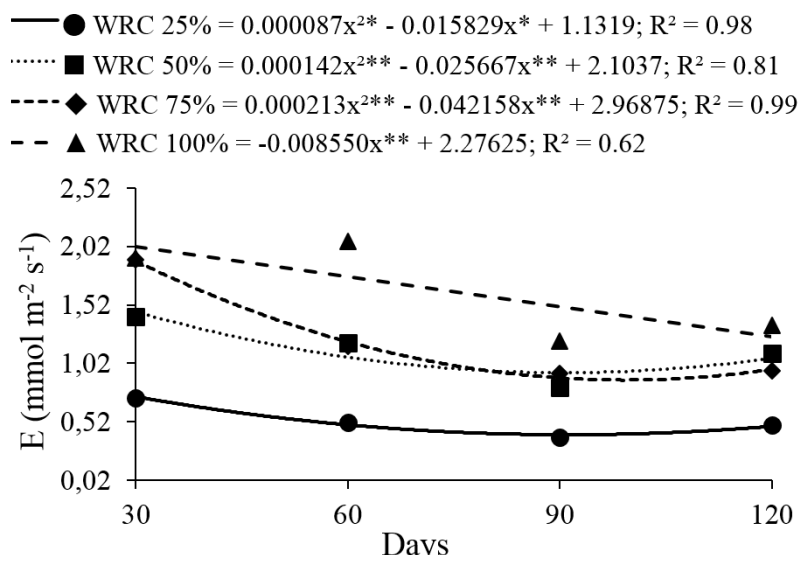

b)

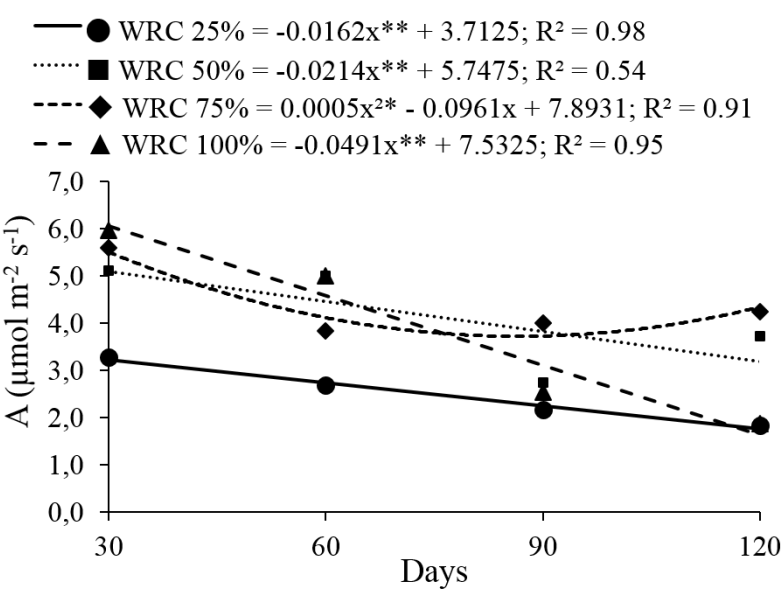

d)

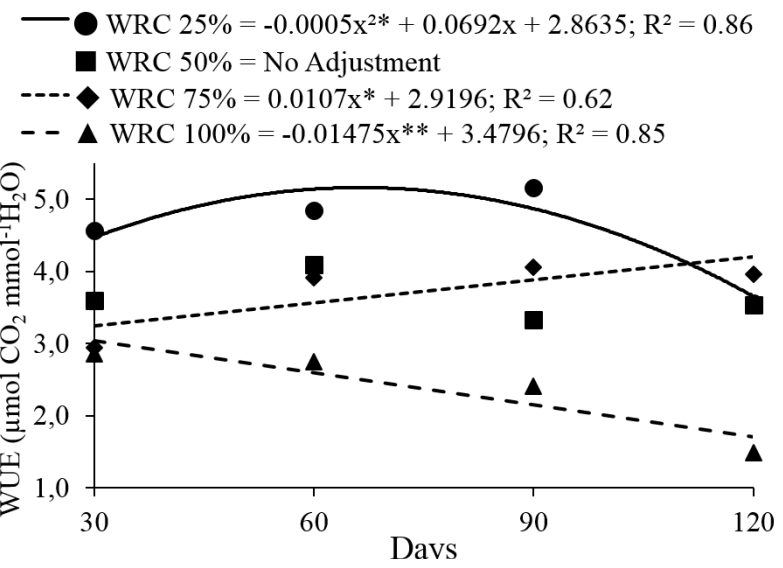

Figure 2 - Water potential of the leaves - $\Psi_{\mathrm{W}}$ (a) liquid photosynthesis - A (b); transpiration - E (c) and water use efficiency WUE (d) in Copaifera langsdorffii Desf. depending on different water retention capacity (WRC) and time.

4b) values increased over time under the $25 \%$ and $75 \%$ WRC treatments, and the average value was higher for seedlings cultivated under $25 \%$ WRC. For seedlings cultivated under $100 \%$ WRC, the stomatal index presented a opposite behavior, decrease over time, with the lowest value $(9.96 \%)$ at 120 days.

Superoxide dismutase activity in the leaves (Figure 5a) was highest in seedlings cultivated under $25 \%$ and $100 \% \mathrm{WRC}$, and in roots under $25 \%$ WRC (Figure 5b). The peroxidase content in the leaves (Figure 5c) remained high under the 25\% WRC treatment throughout the evaluation; however, it tended to decrease, reaching a minimum value of $0.65 \mu \mathrm{Kat} \mu \mathrm{g} \operatorname{Prot}^{-1}$, at 86.78 days. For seedlings cultivated under $75 \% \mathrm{WRC}$, the values increased and reached the highest value at the end of the evaluation, with values similar to those for seedlings cultivated under 25\% WRC. Peroxidase activity in the roots (Figure 5d) increased as water availability increased, with the highest values (1.85 $\mu$ Kat $\mu \mathrm{g} \mathrm{Prot}^{-1}$ ) under the $100 \%$ WRC treatment. As for catalase activity in the roots (Figure 5e), the highest value was observed in the seedlings after 30 days of cultivation under $100 \% \mathrm{WRC}$, and the minimum value $\left(1.20 \mu \mathrm{Kat} \mu \mathrm{g} \mathrm{Prot}^{-1}\right)$ was observed for seedlings cultivated under $50 \% \mathrm{WRC}$ at 55.26 days. 
a)

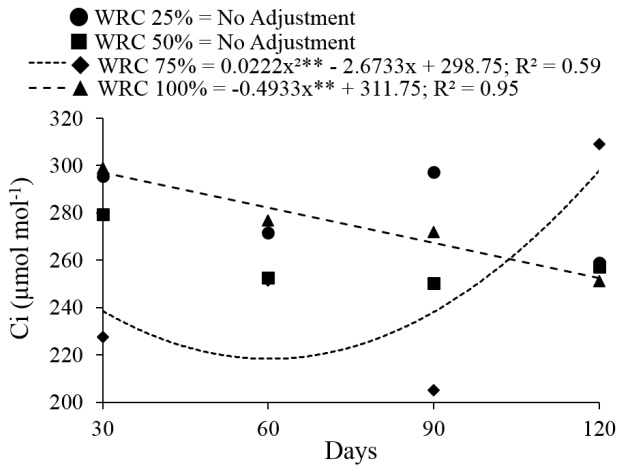

c)

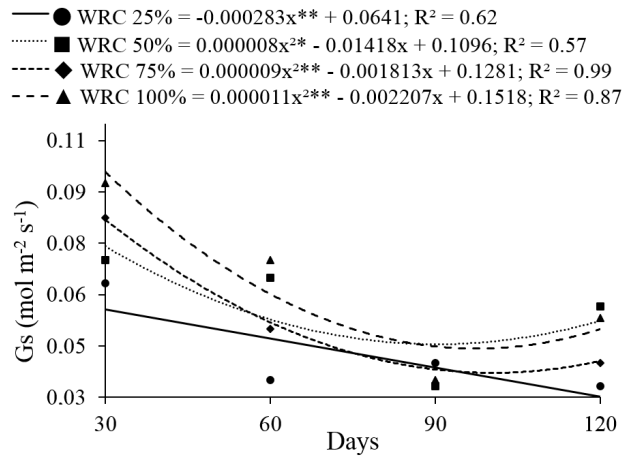

b)

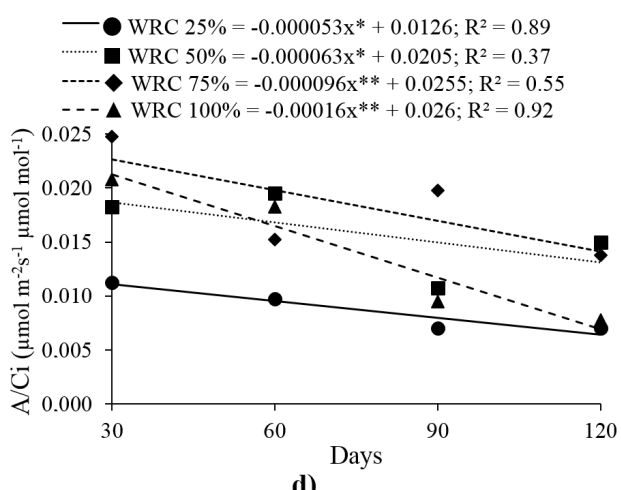

d)

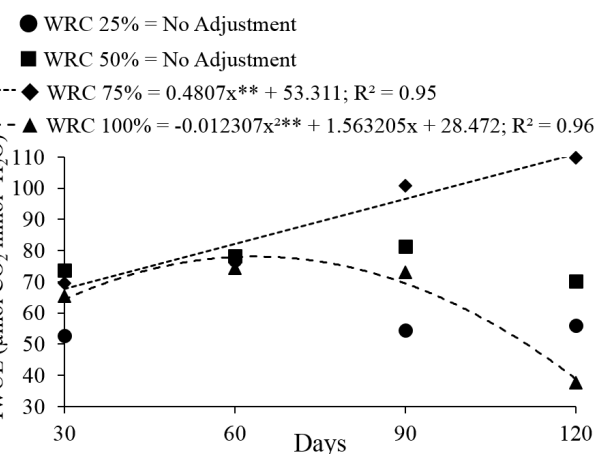

e)

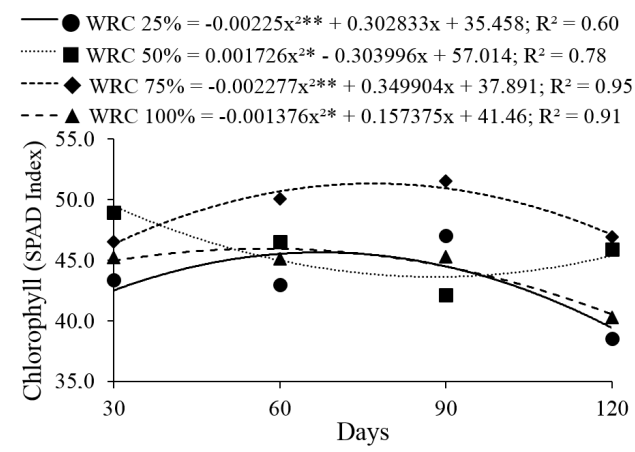

Figure 3 - Internal carbon dioxide gas - Ci (a), Carboxylation efficiency of rubisco - A/Ci (b); Stomatal conductance - gs (c), intrinsic water use efficiency - IWUE (d) and Chlorophyll (e) in Copaifera langsdorffii Desf. depending on different water retention capacity (WRC) and time.

\section{DISCUSSION}

It is interesting to note that, under different conditions of water availability, Copaifera langsdorffii leaves did not present a significant difference in their water potential $\left(\Psi_{\mathrm{w}}\right)$. A potential reason is that, the species presents resources to adapt to the changes of the environment (represented in this study by different WRC values). Trovão et al. (2007) evaluated the water potential of 11 tree species from Caatinga, in the dry and rainy seasons, and observed that seven species of the total did not present significant differences in the water potential across the two seasons. The most interesting explanation utilizes the fact that plants, in order to minimize water loss and maintain turgidity for a period of time, present physiological changes. 
a)

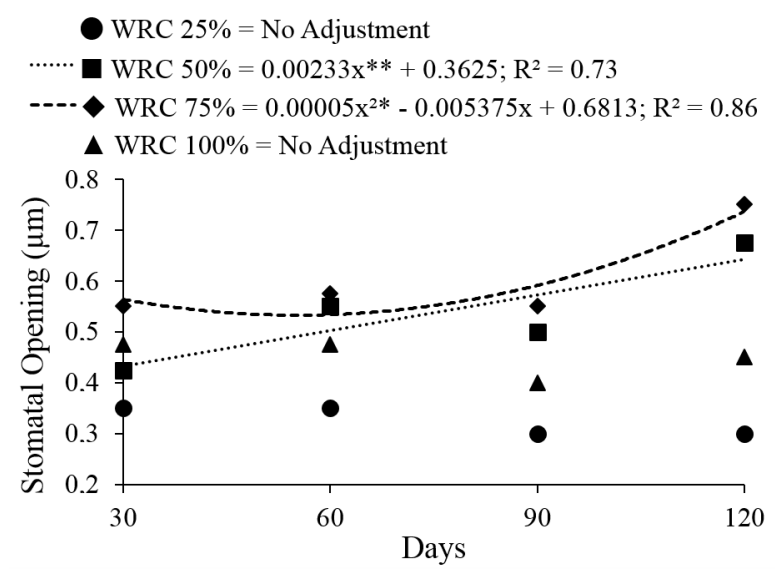

b)

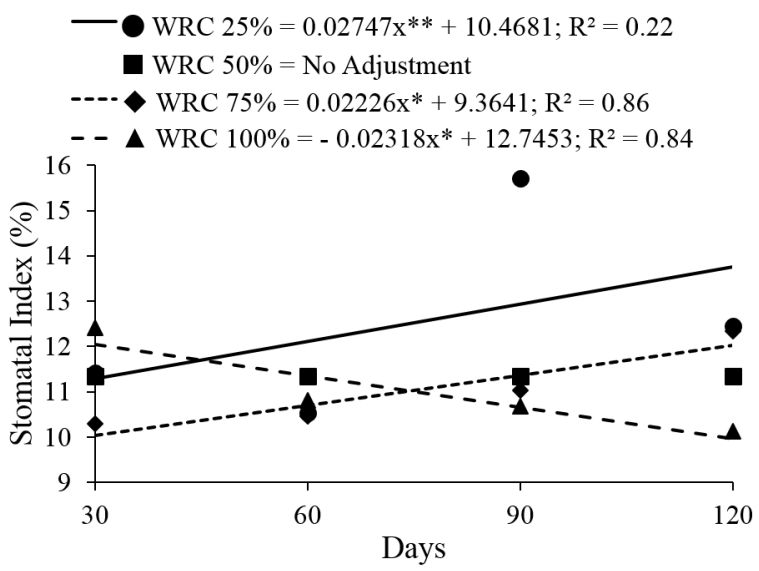

Figure 4 - Stomatal opening (a) and stomatal index (b) in Copaifera langsdorffii Desf. depending on different water retention capacity (WRC) and time.

The $\Psi_{\mathrm{w}}$ response pattern in $C$. langsdorffii seedlings might also be a response to the environmental conditions during the study period. In the days prior to the 30 and 120-day evaluations, the relative humidity of the environment was low, which could have contributed to low water availability in the seedling tissues, compared with the other evaluation periods. However, not all physiological relationships evaluated under different WRC treatments were negatively affected by this environmental condition.

Although the observed average value of $\Psi_{\mathrm{w}}$ for $C$. langsdorffii plants has been considered in the literature as a limiting factor for the development of several species, the value obtained for $\mathrm{F}_{\mathrm{v}} / \mathrm{F}_{\mathrm{M}}$, regardless of the evaluated treatments, was 0.70 . This result suggests that the plants showed very little reduction towards the critical limit, suggesting that they have some evolutionary characteristic to tolerate water shortage. According to the literature, $\mathrm{F}_{\mathrm{V}} / \mathrm{F}_{\mathrm{M}}$ decreases under conditions of low water availability, leading to an increase in the photoinhibition processes (Lage-Pinto et al. 2012).

Results similar to those obtained for $C$. langsdorffii seedlings were also observed by Trovão et al. (2007) in their study on Caatinga trees; four of the seven species that did not present significant alterations in $\Psi_{\mathrm{w}}$ (Myracrodruon urundeuva Allem., Amburana cearenses Allem., Commiphora leptophloeos Mart., and Maytenus rigida Mart.) did not present changes in $\mathrm{F}_{\mathrm{V}} / \mathrm{F}_{\mathrm{M}}$ either. Campelo et al. (2015) observed a reduction in this trait in only three of the evaluated tree species (Calophyllum brasiliense Cambess., Swietenia macrophylla King, and Handroanthus serratifolius Vahl), and only when the seedlings were subjected to a severe water stress, with $F_{V} / F_{M}$ values varying from 0.555 to 0.619 .

Photosynthetic rate decreased for most WRC values. The highest decrease occurred under the 100\% WRC treatment (Figure 3a), which suggests that the $100 \%$ constant maintenance of WRC led to an effective decrease in the amount of air around the roots. This would impair the water absorption, which could consequently affect the photosynthetic process to a greater extent than under the $25 \%$ WRC treatment, wherein the values remained low throughout the experimental period. These results suggested a water stress in C. langsdorffii seedlings under the $100 \%$ WRC treatment.

After 120 days of evaluation, it was possible to observe that the seedlings cultivated under $75 \%$ WRC presented the highest photosynthetic rates and WUE. This was the only treatment where these characteristics continuously increased with time, 
which might be justified by the higher observed stomatal opening that allows better internal carbon input and water vapor release. Very low values of transpiration and/or very high photosynthetic rate contribute to the elevation of the WUE. In this experiment, under the $25 \%$ WRC treatment, low transpiration led to the highest WUE values. On the other hand, the high photosynthetic rate observed under the $75 \%$ WRC treatment resulted in increasing values of WUE over time.

Higher values of WUE are characteristic of plants tolerant to lower availability of water resources (Ma et al. 2004). Moreover, they serve as an indicative parameter for the physiological plasticity of the plants with respect to the abiotic factors. In other words, the values of WUE represent the ability of the species to adapt to environmental adversities. In the case of $C$. langsdorffii seedlings, this fact is evident between 30 and 90 days of the experimental period, wherein the highest value of WUE was recorded under the $25 \% \mathrm{WRC}$ treatment. However, this value decreased over time, which indicates that C. langsdorffii is vulnerable to extended periods of low water availability (Figure 3c).

The IWUE was highest in the $75 \%$ WRC treatment, demonstrating that this WRC value was the most favorable for gas exchange in $C$. langsdorffii seedlings, in comparison with the other treatments. High values of IWUE and WUE are usually the characteristics of plants tolerant to low water availability in the soil (Ferreira et al. 2012), which is the most favorable condition for the cultivation of $C$. langsdorffii seedlings.

As observed in Figure $4 \mathrm{c}$, the stomatal conductance (gs) up to the 60 days of evaluation presented a trend consistent with the different WRC values, because the lower the water availability, the lower the gs values, which was an immediate and strategic response of the plants to reduce the water loss by transpiration, avoiding dehydration of the tissues (Albuquerque et al. 2013). This fact is evident from the similarity between the transpiration curves (Figure $3 \mathrm{~b}$ ) and the stomatal conductance curves, for the $50 \%$ and $75 \%$ WRC treatments, which confirms the existing relationship.

In the $75 \%$ WRC treatment, a low $\mathrm{Ci}$ and a decrease in its values, up to 60 days of cultivation, were observed. This was followed by an increase in these values, which would explain the pattern of decreasing response during the experimental period, for both the photosynthetic rate and the $\mathrm{A} / \mathrm{Ci}$.

The decreasing values observed for the $\mathrm{A} / \mathrm{Ci}$ under the $25 \%$ and $100 \%$ WRC treatments during the experimental period might be a consequence of water deficit and an effective decrease in the amount of air in the substrate, respectively. Both of these factors could cause damage to the photosynthetic apparatus, which might lead to the impairment and reduction of Rubisco activity (Flexas et al. 2006, $\mathrm{Xu}$ et al. 2009).

A similar trend was observed for the chlorophyll index. The highest values were observed under $75 \%$ WRC, and the lowest values were observed under $25 \%$ and $100 \% \mathrm{WRC}$ treatments. This result indicates that the water stress accelerated the degradation of chlorophyll contents (Mafakheri et al. 2010), which might have affected the conditions for photosynthesis in the plants, via a reduction in the amount of energy absorbed by the light-harvesting complex (Baker 2008). However, during the experimental period, no typical chlorosis, resulting from low amounts of chlorophyll, was observed.

Although the number of stomatal openings was high under $75 \%$ and $50 \% \mathrm{WRC}$, the same trend was not observed for the stomatal conductance, which had the highest value under $100 \%$ WRC. These results confirm that these characteristics are not directly related or dependent, and the maintenance of stomatal openings does not represent a high diffusion of $\mathrm{CO}_{2}$ and water, as observed in plants cultivated under $75 \% \mathrm{WRC}$, where in a reduction in the transpiration was noted before the decrease in the photosynthetic rates, resulting in an influx of $\mathrm{CO}_{2}$ and low water loss due to transpiration. 
a)

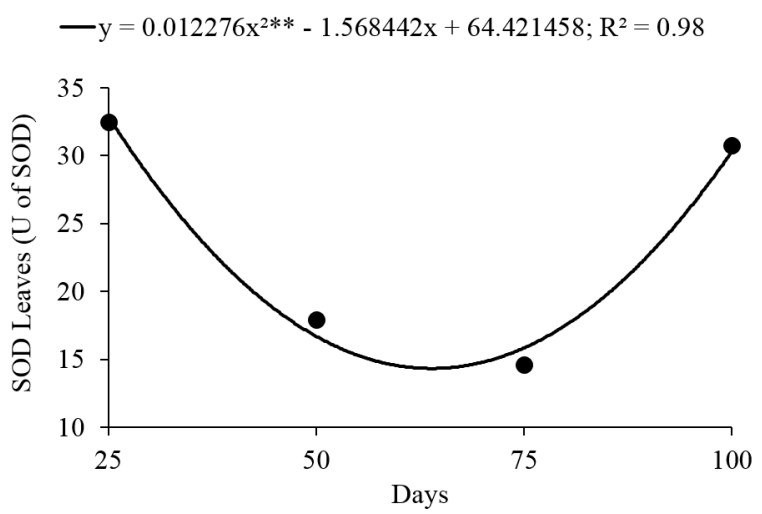

c)

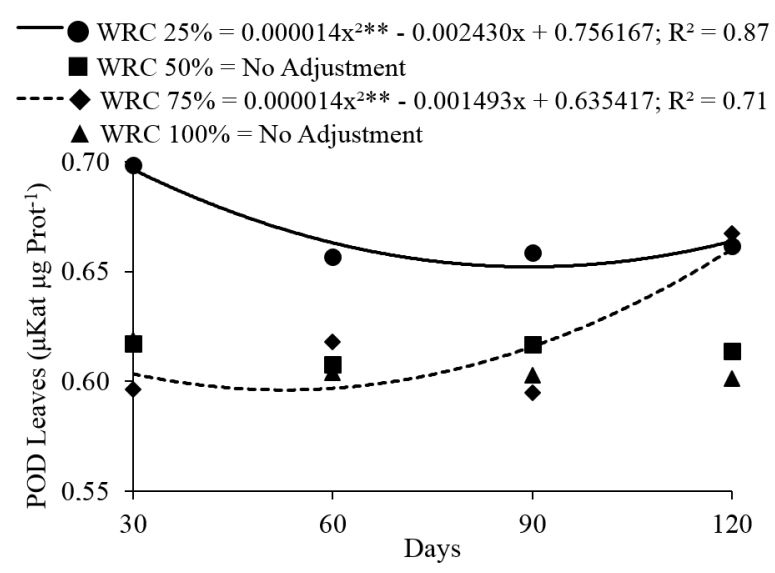

b)

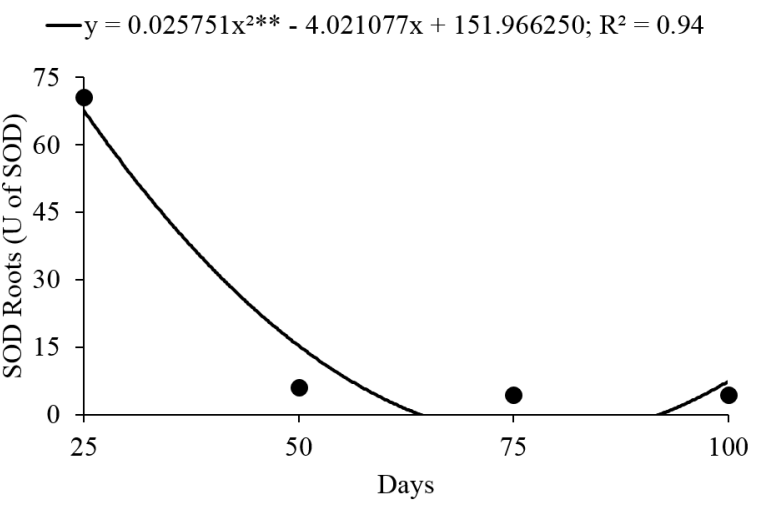

d)

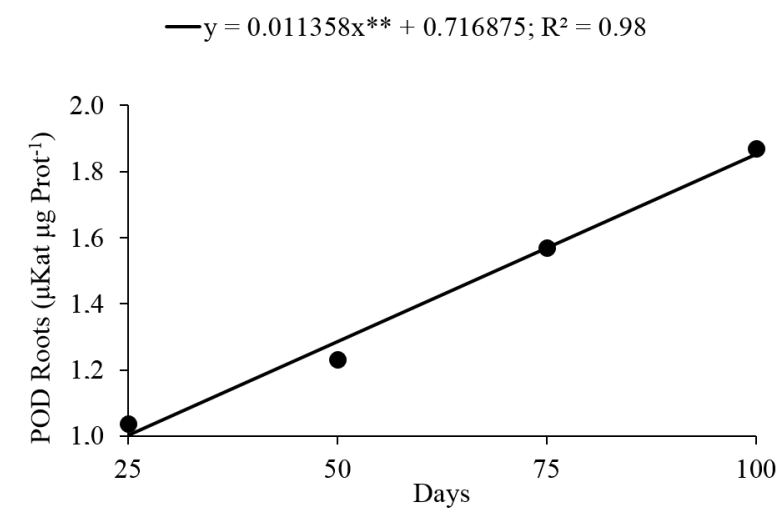

e)

- WRC $25 \%=$ No Adjustment

WRC $50 \%=0.000041 \mathrm{x}^{2 *}-0.004532 \mathrm{x}+1.3290 ; \mathrm{R}^{2}=0.63$

- WRC $75 \%=$ No Adjustment

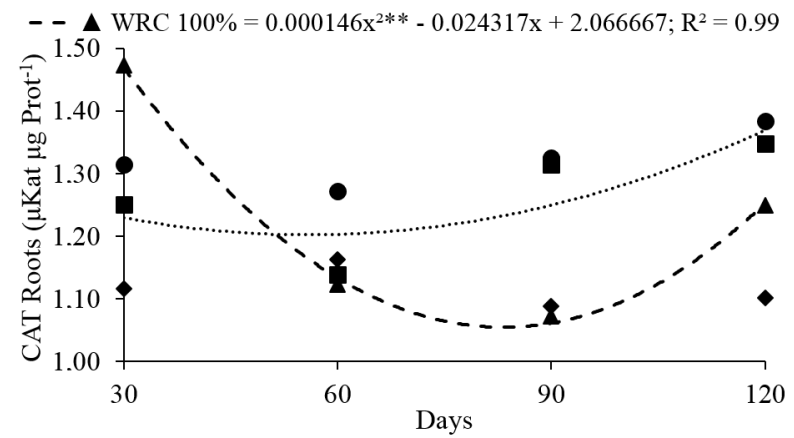

Figure 5 - Enzymatic activity of Superoxide dismutase in leaves - SOD (a) and roots (b); of Peroxidase in leaves - POD (c) and roots (d) and Catalase in leaves - CAT (e) in Copaifera langsdorffii Desf. depending on different water retention capacity (WRC) and time. 
However, the water deficit caused several changes, as represented by the reduction in the number of stomatal openings. In the literature, stomatal changes (density, index, opening, size, diameters) are related to the regulation of gas exchange under stress conditions. Therefore, leaves with fewer stomatal openings show higher efficiency under water-deficit conditions, because they present a smaller size of the stomatal pores, which reduces water loss through transpiration (Boeger and Wisniewski 2003, Souza et al. 2010, Taiz and Zaiger 2013). In the case of C. langsdorffii seedlings, the reduction in the stomatal opening was a quick response to the water deficit, a strategy adopted to avoid water loss under a stress condition. However, it led to a reduction in the transpiration and photosynthetic rates.

The activity of superoxide dismutase, in both leaves and roots, was higher at the extremes of WRC, suggesting that such conditions $(25 \%$ and $100 \% \mathrm{WRC}$ ) represent a growth-limiting condition for C. langsdorffii seedlings. Regarding peroxidase, its activity in the roots was more intense under $25 \%$ WRC than in the other treatments. However, an inverse trend was observed in the leaves; with increasing water availability, its activity increased. This fact suggests that different parts of the plant respond differently to the mechanisms of stress protection, and in the specific case of peroxidase, this could be due to its polymorphism. Therefore, this enzyme has different functions in each plant part (organ or cell compartment), which contributes to a better adaptation of the plant in the environment (Oliveira et al. 2008, Taiz and Zeiger 2013).

Regarding the catalase activity in the roots, although the data did not fit well to the tested equations, it can be seen that the highest values were generally recorded in the $25 \% \mathrm{WRC}$ treatment. Seedlings cultivated under $75 \%$ and $100 \%$ WRC presented a low CAT activity during the experimental period, except at 30 days of cultivation under $100 \%$ WRC, which could be attributed to the fact that the seedlings were still too young to support a large amount of water in the substrate, and consequently, increased the catalase production in response to a momentary oxidative stress.

Abiotic stress conditions might be related to the production of reactive oxygen species, which alter the cellular metabolism. It is known, however, that adaptation to water stress might be related to the ability of plants to maintain high levels of antioxidants in their tissues, such as the enzymes superoxide dismutase, peroxidase, and catalase, thus, activity of such enzymes constitutes an important parameter for quantifying plant responses to environmental stresses (Shao et al. 2007, Oliveira et al. 2008, Pompelli et al. 2010, Taiz and Zeiger 2013).

Previous studies have shown that water stress can cause reduction in the contents of photosynthetic pigments due to oxidative damage in plants; thus, the plants protect themselves by synthesizing carotenoids and increasing the content of enzymes such as peroxidases (Egert and Tevini 2002). It is noteworthy that this behavior was observed in the C. langsdorffii seedlings in the present study.

It is interesting to note that, among the enzymes quantified in $C$. langsdorffii seedlings, SOD was the most sensitive parameter for the detection and protection to stress. Similar results were also observed in Jatropha curcas L. subjected to water deficit (Pompelli et al. 2010). However, in the 11 different genotypes of Triticum aestivum L. evaluated by Shao et al. (2007), the differences in the expression of antioxidant enzymes under stress conditions might have been due to several factors, such as gene expression, cultivation site, atmospheric pressure, and natural and artificial selection.

\section{CONCLUSION}

Copaifera langsdorffii Desf. seedlings presented the highest gas exchange, photoassimilate production, WUE, and maintenance of the photosynthetic 
apparatus, when cultivated on a substrate with $75 \%$ WRC. During the evaluation period, the efficiency of photosystem II was not significantly altered by any of the treatments. Extreme treatments, in terms of water availability, represented by $25 \%$ and $100 \%$ WRC, resulted in water stress for this species, leading to a high activity of antioxidant enzymes.

\section{ACKNOWLEDGMENTS}

The authors are grateful for the financial suport by Fundação de Apoio ao Desenvolvimento do Ensino, Ciência e Tecnologia do Estado de Mato Grosso do Sul (FUNDECT-MS), the Coordenação de Aperfeiçoamento de Pessoal de Nível Superior (CAPES) and Conselho Nacional de Desenvolvimento Científico e Tecnológico (CNPq).

\section{REFERENCES}

ALBUQUERQUE MPF, MORAES FKC, SANTOS RIN, CASTRO GLS, RAMOS EMLS AND PINHEIRO HA. 2013. Ecofisiologia de plantas jovens de mogno-africano submetidas a déficit hídrico e reidratação. Pesq Agropec Bras 48(1): 9-16.

BAKER NR. 2008. Chlorophyll fluorescence: a probe of photosynthesis in vivo. Annu Rev Plant Biol 59: 89-113.

BOEGER MRT AND WISNIEWSKI C. 2003. Comparação da morfologia foliar de espécies arbóreas de três estádios sucessionais distintos de Floresta Ombrófila Densa (Floresta Atlântica) no sul do Brasil. Rev Bras Bot 26: 61-72.

BROETTO F. 2014. Métodos de trabalho em bioquímica vegetal e tecnologia de enzimas. Coordenador: Fernando Broetto - Botucatu: IBB, Cultura. Acadêmica, 2014. UNESP, São Paulo, 92 p.

CALDATO SL AND SCHUMACHER MV. 2013. O uso de água pelas plantações florestais - uma revisão. Ciênc Florest 23(3): 7-516.

CAMPELO DH, LACERDA CF, SOUSA JA, CORREIA D, BEZERRA AME, ARAÚJO JDM AND NEVES ALR. 2015. Trocas gasosas e eficiência do fotossistema II em plantas adultas de seis espécies florestais em função do suprimento de água no solo. Rev Árvore 39(5): 973-983.

CUNHA RLM, FILHO BGS, COSTA RCL AND VIÉGAS IJM. 2013. Physiological assessment in young Brazilian and African mahogany plants during the dry and rain seasons in northeastern Para state. Brazil Ciênc Agrotec 56(3): 255-260.

EGERT M AND TEVINI M. 2002. Influence of drought on some physiological parameters symptomatic for oxidative stress in leaves of chives (Allium schoenoprasum). Environ Exp Bot 48: 43-49.

FERREIRA DF. 2010. Programa de análises estatísticas (Statistical Analysis Software) e planejamento de Experimentos - SISVAR 5.3. Lavras: UFLA.

FERREIRA MJ, GONÇALVES JFC AND FERRAZ JBS. 2012. Crescimento e eficiência do uso da água de plantas jovens de castanheira-da-Amazônia em área degradada e submetidas à adubação. Ciênc Florest 22(2): 393-401.

FLEXAS J, BARBOUR MM, BRENDELO, CABRERA HM, CARRIQUÍ M, DÍAZ-ESPEJO A, DOUTHE C, DREYER E, FERRIO JP AND GAGO J. 2012. Mesophyll diffusion conductance to $\mathrm{CO}_{2}$ : an unappreciated central player in photosynthesis. Plant Sci 193: 70-84.

FLEXAS J, RIBAS-CARBÓ M, BOTA J, GALMÉS J, HENKLE M, MARTÍNEZ-CAÑELLAS S AND MEDRANO H. 2006. Decreased Rubisco activity during water stress is not induced by decreased relative water content but related to conditions of low stomatal conductance and chloroplast $\mathrm{CO}_{2}$ concentration. New Phytol 172(1): 73-82.

GONÇALVES JFC, SILVA CEM AND GUIMARÃES DG. 2009. Características fotossintéticas e potencial hídrico foliar de plantas jovens de andiroba submetidas à deficiência hídrica e à reidratação. Pesq Agropec Bras 44(1): 8-14.

LAGE-PINTO F, BERNINI E, OLIVEIRA JG AND VITÓRIA AP. 2012. Photosynthetic analyses of two native Atlantic Forest species in regenerative under story of eucalyptus plantation. Braz J Plant Physiol 24(2): 95-106.

LORETO F, CENTRITTO M, CHARTZOULAKIS K. 2003. Photosyntheticlimitations in olive cultivars with different sensitivity to salt stress. Plant Cell Environ 26: 595-601.

MA CC, GAO YB, GUO HY AND WANG JL. 2004. Photosynthesis, transpiration and water use efficiency of Caragana microphylla, C. intermedia and C. korshinskii. Photosynthetica 42(1): 65-70.

MAFAKHERI A, SIOSEMARDEH A, BAHRAMNEJAD B, STRUIK P AND SOHRABI Y. 2010. Effect of drought stress on yield, proline and chlorophyll contents in three chickpea cultivars. Aust J Crop Sci 4: 580-585.

NASCIMENTO MEI, BERTOLUCCI SKV, SANTOS FM, SANTOS JÚNIOR JM, CASTROEM AND PINTO JE BP. 2014. Avaliação morfológica de plantas jovens de Copaifera langsdorffii Desf. desenvolvidas em diferentes temperaturas. Rev Bras Plantas Med 16(4): 931-937.

OLIVEIRA JEZ, AMARAL CLF AND CASALI VWD. 2008. Caracterização isozimática e atividade de peroxidase em folhas de plantas hiperídrica, intermediária e normal de 
Bidens pilosa L. mantidas in vitro. Cienc Agrotec 32(1): 32-36.

POMPELLI MF, BARATA-LUÍS R, VITORINO HS, GONÇALVES ER, ROLIM EV, SANTOS MG, ALMEIDA-CORTEZ JS, FERREIRA VM, LEMOS EE AND ENDRES L. 2010. Photosynthesis, photoprotection and antioxidant activity of purging nut under drought deficit and recovery. Biomass Bioenergy 34(8): 12071215.

PORTES MT, ALVES TH AND SOUZA GM. 2006. Water deficit affects photosynthetic induction in Bauhinia forficate Link (Fabaceae) and Esenbeckia leiocarpa Engl. (Rutaceae) growing in under storey and gap conditions. Braz J Plant Physiol 18(4): 491-512.

SAKAMOTO A AND MURATA N. 2002. The role of glycine betaine in the protection of plants from stress: clues from transgenic plants. Plant Cell Environ 25: 163-171.

SALISBURY EJ. 1928. On the causes and ecological significance of stomatal frequency with special reference to the Woodland flora. Phil Trans Roy Soc Lond, Ser B 216: 1-65.

SANTANA DG, LOBO GA, SALOMÃO NA AND PEREIRA VJ. 2016. Robustness of germination na analysis methods for Copaifera langsdorffii Desf. (Fabaceae) seeds. Biosc J 32(1): 160-171.

SCHOLANDER PF, HAMMEL HT, HEMMINGSEN EA AND BRADSTREET ED. 1964. Hydrostatic pressure and osmotic potential in leaves of mangroves and some other plants. Proc Natl Acad Sci 52: 119-125.

SHAO H, CHU L, WU G, ZHANG J, LU Z AND HU Y. 2007. Changes of some anti-oxidative physiological indices under soil water deficits among 10 wheat (Triticum aestivum L.) genotypes at tillering stage. Colloids Surf B: Biointerfaces 54: 143-149.

SOUZA CC, OLIVEIRA FA, SILVA IF AND AMORIM NETO MS. 2000. Avaliação de métodos de determinação de água disponível e manejo da irrigação em terra roxa sob cultivo de algodoeiro herbáceo. Rev Bras Eng Agric Ambient 4(3): 338-342.

SOUZA TC, MAGALHÃES PC, PEREIRA FJ, CASTRO EM, DA SILVA JUNIOR JM AND PARENTONI SN. 2010. Leaf plasticity in successive election cycles of 'Saracura' maize in response to periodic soil flooding. Pesq Agropec Bras 46(1): 16-24.

TAIZ L AND ZEIGER E. 2013. Fisiologia Vegetal, 5 ed., Porto Alegre: Artmed, $918 \mathrm{p}$.

TROVÃO DMBM, FERNANDES PD, ANDRADE LA AND NETO JD. 2007. Variações sazonais de aspectos fisiológicos de espécies da Caatinga. Rev Bras Eng Agric Ambient 11(3): 307-311.

XU Z, ZHOU G AND SHIMIZU H. 2009. Are plant growth and photosynthesis limited by pre-drought following rewatering in grass? J Exp Bot 60(13): 37-49. 